\title{
Nebria Species (Subfamily Nebriinae, Family: Carabidae) from the Romanian Carpathians. Morphological and Molecular Data
}

\author{
Jean Barloy ${ }^{1}$, Florin Prunar $^{2}$, Stephane Dréano ${ }^{3}$, Silvia Prunar $^{2}$, Frédérique Barloy-Hubler ${ }^{4}$ \\ ${ }^{1}$ Agrocampus Ouest Rennes, France; \\ ${ }^{2}$ Banat's University of Agricultural Sciences and Veterinary Medicine „King Michael I of Romania" from \\ Timisoara, Romania; \\ ${ }^{3}$ UMR 6290, CNRS -Institute of Genetics and Development of Rennes (IGDR), Faculty of Medicine, \\ University Rennes I, France; \\ ${ }^{4}$ Plateforme Amadeus-Biosit Rennes I, France
}

Accepted December, 2017

\begin{abstract}
Among the ten species of the Nebria genus, present in the Romanian Carpathians, seven are the object of morphological, geographical distribution and molecular biological studies: Nebria (Eunebria) jockischi hoepfneri Dejean, 1826, Nebria (Boreonebria) heegeri Dejean, 1826, Nebria (Boreonebria) gyllenhali Schönherr, 1806, Nebria (Alpaeonebria) reichei Dejean, 1826, Nebria (Alpaeonebria) reitteri Rybinsky, 1902, Nebria (Alpaeonebria) bissenica Bielz, 1887, Nebria (Nebria) transsylvanica Germar, 1824, Nebria (Nebria) femoralis alpigrada Csiki 1905), collected from the Maramureș Mt., Rodnei Mt., Parâng Mt., Rarău Mt., Făgăraș Mt., Cozia Mt., Bucegi Mt., Retezat Mt., Muntele Mic and Semenic Mt.

The morphological description exploits the body size, the elytral reflection, the colour of the appendages and the legs, the shape of the first antennary segment, its chaetotaxy and that of the submentum, the shape and size of the elytra and alae, the position of the bristles on the ventrites 4-5-6. The shape of the first antennary segment and its chaetotaxy appear as more discriminating criteria, but supposes the integrity of the bristles. The identification is sometimes malaise due to the fragility of the bristles (first antennomere, submentum). Nebria (Alpaeonebria) reichei Dejean, 1826 has a variable chaetotaxy of antenna, 1 to 3 bristles on the first antennomere. The individuals with yellow appendages and legs provided with 2 unequal length can be confused with transsylvanica. They are distinguished by the triangular shape of the aileron (S-shaped in transsylvanica). Molecular data are given for the first time on Carpathian Nebria. The mitochondrial markers (COI I, cyt b) clearly identify the species studied and confirm that alpigrada does not belong to transsylvanica. The results show an infraspecific variability of geographic and altitudinal origin in jockischi one of the most widespread species (gyllenhali, jockischi, reichei).
\end{abstract}

Keywords: Nebria, geographical distribution, morphology, molecular systematics.

\section{Introduction}

\section{STUDY FRAMEWORK}

The Carpathians of Romania host about ten species of the genus Nebria above an altitude of 800-1000 m [1]. They include rare species like $N$. (Boronebria) heegeri Dejean 1826, perhaps

$* \quad$ Corresponding author: Florin Prunar,
fvprunar@gmail.com

(cc) $\mathbf{B Y}$-NC-ND ○ 2017 Jean Barloy et al., published by De Gruyter Open This work was licensed under the Creative Commons Attribution-NonCommercialNoDerivs 3.0 License underestimated because of identification difficulties and considered vulnerable (IUCN code) in Ukraine and Romania [2], and localized ones, such as N. (Alpaeonebria) bissenica Bielz 1887 $[3,4,5]$ and $N$. (Alpaeonebria) carpathica Bielz 1850.

Various prospectings carried out in the mountains of Maramureș, Rodnei, Rarău, Muntele Mic, Făgăraș, Bucegi, Parâng, Cozia, and to their foothills provided 7 species of Nebria.

These are described below, based on morphological characteristics and molecular data 
(except bissenica and heegeri which were captured in small numbers).

\section{Material and Methods}

The insects were captured under stones, in torrents or in the vicinity of snow creek streams and are placed immediately in $95^{\circ}$ ethanol and then stored at $-20^{\circ} \mathrm{C}$. The provenance of the analyzed specimens is the Romanian Mountains: Rodna, Parâng, Rarău, Făgăraș, Cozia, Bucegi, Retezat, Muntele Mic and Semenic. The analysed species are those described above except bissenica which was found in too low numbers. Nebria brevicollis Fabricius 1792 was added from Greci TL and Cozia Top (Vâlcea County). The molecular analysis was conducted on 2 individuals ( 1 male and 1 female); in the event of a strong divergence of sequencing results, the number is doubled. The extraction of the DNA made on the femurs of the four hind legs of the insect. The methods for purification extraction, PCR, and DNA sequencing are those described in a previous study [6].

- Choice of markers:

-Nuclear marker: 29S 5F5R

-Mitochondrial markers: COI I: ICO 1490, HCO

2198 [7], cyt b: CP1 (Harry et al 1998), CB2

[8].

-Sequence analysis

Sequencing results: nuclear marker; mitochondrial markers in concatenation COI I / cyt b were analysed using two matrices:

-The genetic distance (K2P) and the number of different base pairs. This one records all the substitutions whatever is their nature.

-The matrix K80 of Kimura, taking into account the transition-transversion processes.

Sequences were analysed using the Geneious software Version 10. Multiple alignments were performed with the algorithm MAFFT [9]; and the phylogenetic trees were constructed using the algorithm PHYML [10] with the substitution model IC69.

\section{Results and Discussions \\ 1. MORPHOLOGICAL DESCRIPTION}

The main distinctive characters of the ten subalpine and alpine Nebria species of the Romanian Carpathians were briefly presented earlier [1] in the form of tables. The following descriptions (for seven species) provide details and illustrate the most relevant identification criteria.

These include:

-the color of the appendages and the various parts of the legs, -the form of the first antennary segment and the two following, their chaetotaxy and that of the submentum,

-the elytra and alae (membranous wings, hind wings), an important but rarely exploited character,

-the chaetotaxy of the ventrites 4-5-6 when it is useful to confirm identification (genus Boronebria).

The use of chaetotaxy (antenna, submentum, ventrites), an important element of identification, requires the integrity of bristles, that are very fragile elements, especially those of the submentum. Their partial or total absence makes identification impossible or uncertain; the importance of the forewings (elytra) or hind wings (ailerons) being of some help.

\subsection{Ubiquitary Nebria}

Two Nebria have a very wide geographical distribution, which occur in the mountains of Romania from the foothill to the summit [11, 12, 13, 14]:

-Nebria (Eunebria) jockischi hoepfneri Dejean 1826 [15].

-Nebria (Boronebria) gyllenhali Schönherr 1806 often referred to with its former name: rufescens Storm 1768.

Considered as glacial relics, they are found at high altitudes (2300-2400 m), for example in the Austrian (Oetzal) and Italian [16]. Alps and constitute pioneer riparian species colonizing areas liberated by the retreat of glaciers $[17,18,19]$. Although with highly developed membranous wings, folded under the elytra (Figure 1), their ability to fly is unknown. They occupy a wide altitudinal range, raising the question of the modalities of settlement (flight, drift by water to the low parts).

1.1.1. Nebria (Eunebria) jockischi hoepfneri Dejean 1826 ; synonyms: nigricornis Villa, atterima Fiori 1896. Described by Dejean, the type was not found in the collection 'Chaudoir' of the MNHH Paris [20], but the species is reported in several ancient documents of the mountains of Banat.

-Black species, shiny elytra with varying size according to the altitude: $13-14 \mathrm{~mm}$ at the base of the mountains; $7-8 \mathrm{~mm}$ at the summit. -Third elytral interval without discal pore. -Head with a red stain frequent at the vertex, sometimes absent (var. nigriceps Schifshy 1888, individual variation).

-Appendices of the extremities reddish brown, tarsi often brown fairly light (sometimes blacks), antennae brown from 4. antennal segment. 
-The first antennomere subcylindrical, rather big compared with the following ones, with a rather long bristle upsides; slightly conical with 3-4 bristles implanted on the periphery.

-Submentum with 2 bristles, very rarely 3.

-Membranous wings are complete, very developed, folded under the elytra.

Very hygrophilous species, found near the streams, in the banks or under the stones and immersed trunks. Captured in several localities, in medium and high altitude: Văliug 639 m., Muntele Mic 845 m., Latoritei Valley 300-400 m., Rarău Mountains 1200 m., Bucegi Mountains (Piatra Arsă 1950m.), Făgăraș Mountains along the Transfăgărășan Route 1410 m, 1613 m., 1844 m., 1944 m.

\section{Nebria (Eunebria) jockischi hoepfneri Dejean 1826 Nebria (Boronebria) gyllenhali Schönheer 1806}

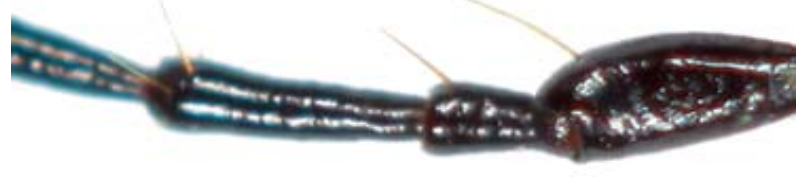

Bristles of the firsts three antennomeres
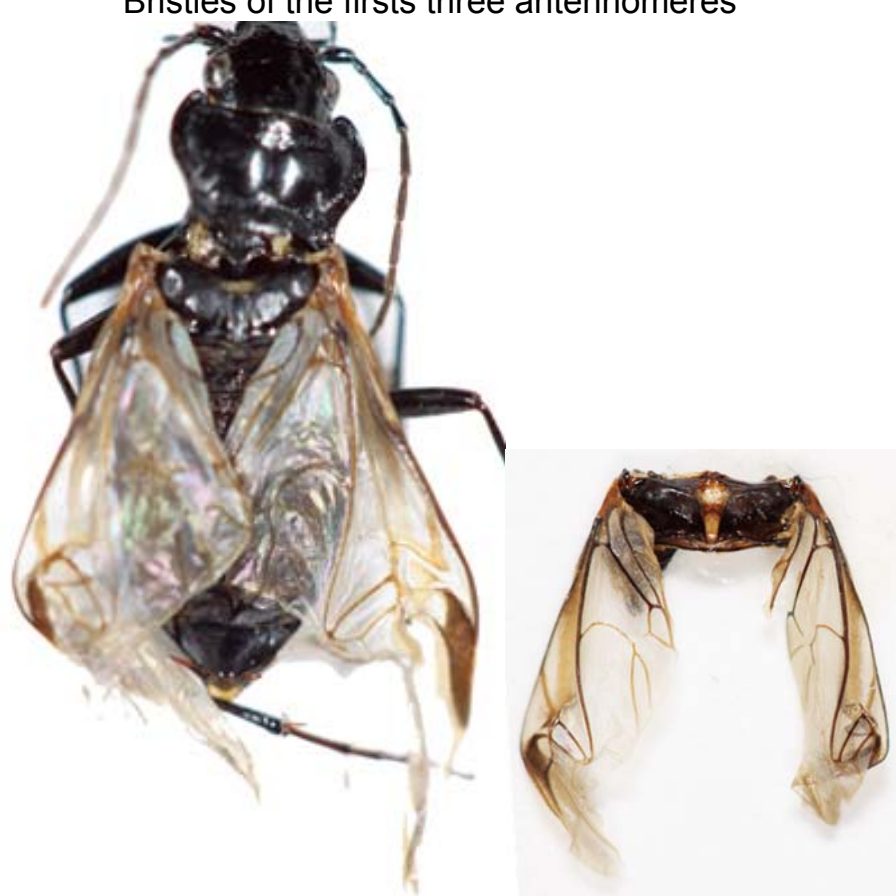

Developed membranous wings

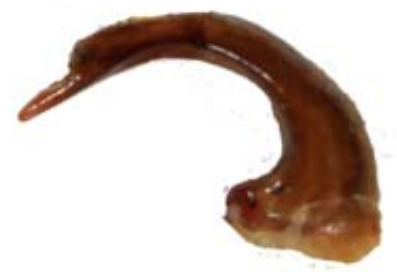

Aedeagus

Figure 1. Morphological aspects of jockischi and gyllenhali

\subsubsection{Nebria (Boreonebria) gyllenhali (Schönherr 1806) [21]; synonym rufescens Strom 1768 \\ -Black species with shiny elytra. Size varying} according to the altitude: $13-14 \mathrm{~mm}$ at the foothills of the mountains, $9-10 \mathrm{~mm}$ at the top. -Third elytral interval with typically 4-5 discal pores but in variable number for the individuals of higher altitude.
-Distal parts of the appendages and antennae, brightened, brown, slightly reddish, sometimes legs totally reddish yellow (form balbi).

-First antennomere long-ovoid, narrowed at the base with a long apical bristle; second antennomere very short with a short bristle underneath; third antennomere rather long with generally 2 bristle above, 2 bristle below. -Submentum with 8-10 bristles. 
-Ventrites 4-5-6 with one bristle on each side of the middle.

-Membranous wings are complete, well developed, folded under the elytra.

-Possible confusion with:

-jockischi hoepfneri (when red stain vertex is undetectable) species with 2-3 bristles to the ventrites 4-5-6,

-heegeri, a smaller species, with reduced membranous wings, the second antennnomere with 2 bristles ( 1 above, 1 below).

- Species habitat and locations:

- very hygrophilous, encountered under stones, in torrents at medium altitude in streams or in the immediate vicinity of high-altitude areas,

- very frequent and present in a wide altitudinal range: Latorița Valley 210 m., Muntele Mic 845 m., Făgăraș to the various altitudes from $1800 \mathrm{~m}$. to 2089 m, Rodnei Mountains (1845 m), Bucegi Mountains (Piatra Arsă 1950).

\subsection{Carpathian species}

1.2.1. Nebria (Boronebria) heegeri Dejean 1826

Endemic species of the Romanian and Ukrainian Carpathians, considered rare and threatened with extinction [2].

In Ukraine $[22,23,24]$ is located at the Chornogora and Gorgany Mountains, on the mountain forest zone [25, 26, 27].

In Romania: the species formerly cited by [28, 29] in the mountains Retezat (Zanoaga Lake), Cindrel, Făgăraș (Balea Lake), Bucegi, Rastolita, Ciucas and rarely reported since in the recent faunistical studies, except Ciucas Mountains (Berk Patak 1160 m.) [30].

-Black shiny insect, 10-12 mm., the appendices low or not brilliant.

-Third elytral interval with 2-3 disc pores.

-First antennomere is conical, large and quite long with a long apical bristle. Second antennomere is shorter, conical with a bristle above and another below often implanted obliquely. Third antennomere is long, conical with 3 bristles on the perimeter.

-Submentum with 4 bristles.

-Ventrites 4-5-6 with 1 bristle.

-Reduced membranous wings, fairly large.

In partial or total absence of antenna and/or submentum bristles, the species can be confused with gyllenhali. It differs from gyllenhali by more oval shape of elytra, sloping shoulders and conical first antennomere

-Distinction from Boronebria species:

-Species with highly developed membranous wings:

-Head with red stain to vertex; ventrites 4-5-6 with 2-3 bristles.........jockischi hoepfneri Dejean 1826
-Head without vertex stain; ventrites 4-5-6 with 1 bristle....................gyllenhali Schönherr 1806 -Species with reduced membranous wings:

-Head without vertex stain; ventrites 4-5-6 with 1 bristle..........................heegeri Dejean 1826

\subsubsection{Group transsylvanica}

A group comprising two species, morphologically similar and often confused: Nebria (Nebria) transsylvanica Germar 1824 and Nebria (Nebria) femoralis Chaudoir 1843 redescribed by [31], present in the Rodnei Mountains [20]. We did not found the nominate form but collected Nebria (Nebria) femoralis alpigrada Csiki 1906 [32, 12].

\section{- Taxonomic note}

In the literature [33] there is a Nebria femoralis Motshulsky 1859 (synonym nivalis Paykull 1798, Russian species.).

A. Nebria (Nebria) transsylvanica Germar 1824 Species mentioned by Germar from Transylvania [34].

Nebria with shiny black elytra, fairly short (10.5-12 $\mathrm{mm})$, with variable elytral reflection in dark tanned, greenish or purplish.

Appendages (mandibular extremities, palps) antennae, tarsi reddish brown, rarely totally black. Ganglbauer [35,36] mentioned specimens from the top of Kuhorn (Rodnei $2200 \mathrm{~m}$ ) with red legs and other rufinos.

Head with occasionally thinning stain on the vertex.

First antennomere large, short and thick with two bristles implanted close to each other (1 long, 1 short). Second antennomere conical, short with a bristle below; third antennomere of conical shape, long and with 2 bristles above and 1 below.

Submentum with 4 bristles. Alae reduced, S shaped.

This Nebria is present in the Ukrainian Carpathians (Gorgany, Chornagora, Svydovets, Marmarosh Mts) at altitudes above $1400 \mathrm{~m}$, and in varied biotopes: alpine meadows, Pinus mugho settlement, rock outcrops [25]. Neculiseanu [37] quotes her from Moldova, based on the resources of the collection from Academy of Sciences of Moldova. This location deserves confirmation, unless the origin is located at the northern border with the Ukrainian Carpathians.

The species, according to the literature, seems to be common in Romania. Numerous citations of localities are of medium and high altitudes (1600$1800 \mathrm{~m})$ : in Southern Carpathians: Retezat Mountains, Bucegi Mountains, Făgăraș Mountains, Parâng Mountains; but also in the north: Călimani Mountains or recently cited Maramures Mountains [38, 39], Rodnei Mountains $[13,40,41,42,43]$. We collected it only in the Făgăraș Mountains. 
It is possible that the species has been confused in the north (notably Rodna Mountains) with Nebria (Alpaeonebria) reitteri Rybinsky, 1902 because of its similar habitus, distinct by the antennary chaetotaxy (first antennomere with a long bristle, against two with unequal length for transsylvanica). (Figure 2.)

\section{Nebria (Nebria) transsylvanica Germar 1824}
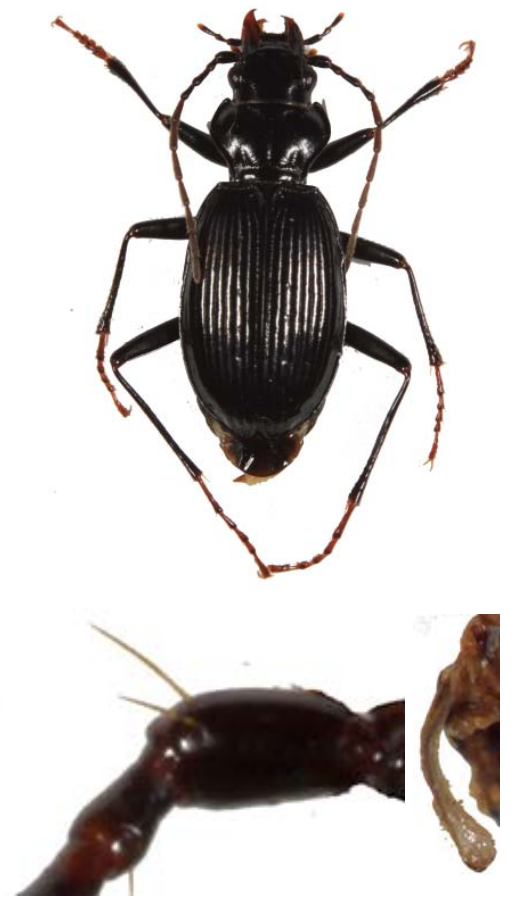

Nebria (Alpaeonebria) reitteri Rybinsky 1902

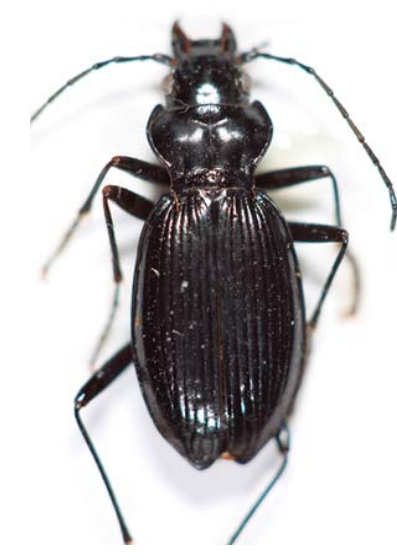

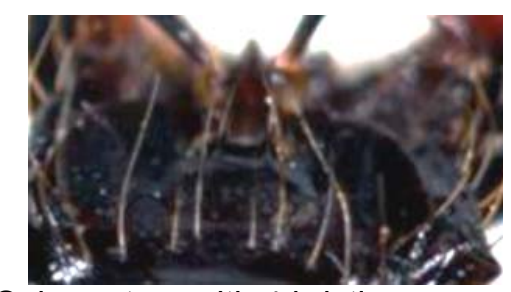

Submentum with 4 bristles on each side of the middle

Figure 2. Morphological aspects of transsylvanica and reitteri

\section{B. Nebria femoralis alpigrada Csiki 1906}

Initially alpigrada Csiki 1906, its synonym ormayi Ganglbauer 1892 was attached to transsylvanica. The attachment to transsylvanica is still adopted in the recent Romanian fauna [14]. Ledoux [20] considers it as a subspecies of femoralis. Its distribution seems to be quite broad: it is mentioned as ormayi (alpigrada) of the Calimani Mountains, Bucegi Mountains [44, 45], populations of Transylvania (attached to transsylvanica) by [29], Retezat Mountains [46, 47].

We captured from two populations morphologically related to alpigrada in the Parângului Mountains at two altitudes $(840 \mathrm{~m}$ and $1848 \mathrm{~m}$., near Pasul Urdele) and in the Retezat Mountains (Poiana Pelegii $1618 \mathrm{~m}$.).

Both have the following characteristics of the species and subspecies: -femoralis: size 11.0 to $12.5 \mathrm{~mm}$, the first cylindrical or sub-cylindrical article with a long bristle, the other characteristics (alae and aedeagus shape) being those of the type.

-alpigrada: shiny black elytra, yellowish appendages and antennae (sometimes slightly reddish); legs altogether of flavescent colour, with darkening of the femur-tibia joint.

Certain forms of reichei with appendages, antennae and legs entirely of yellow colour, could be confused with alpigrada (figure 3,4). However, reichei often holds 2 bristles at the first article of the antenna and the triangular ala shape avoids any confusion (alpigrada having an S-shaped ala). Her geographical distribution and possibly her infraspecific variability (see data of molecular biology) remain to be specified. The prospecting should be carried out in the localities mentioned for transsylvanica alpigrada Csiki. 


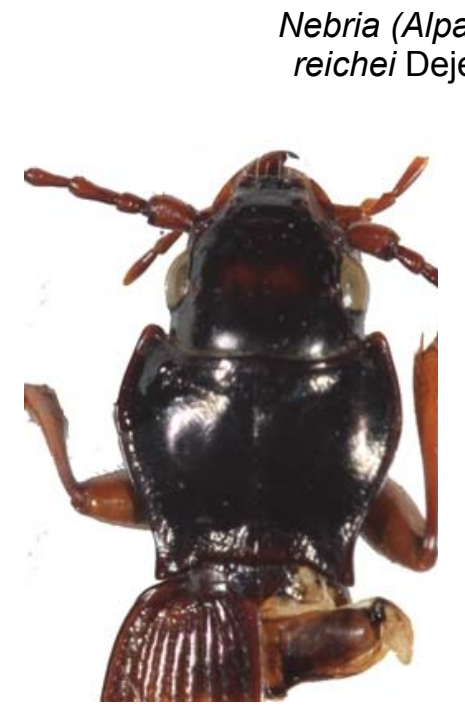

Flavescents legs and triangular alae

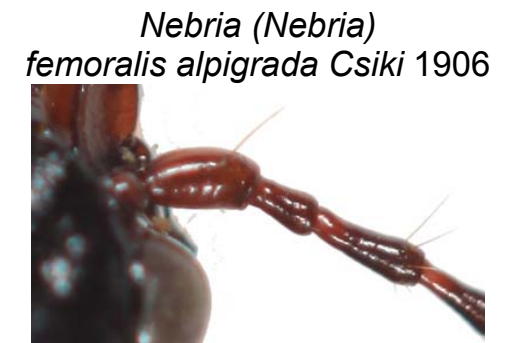

Firtst antennomere with a long bristle above

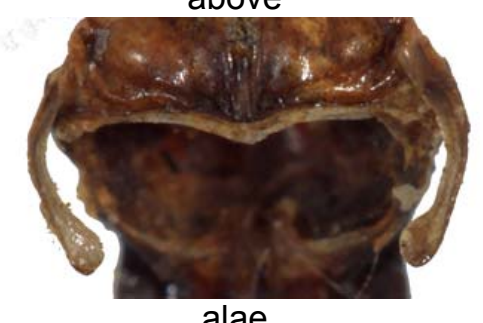

(common form to femoralis and transsylvanica)

Figure 3. Morphological aspects of reichei and femoralis alpigrada

\subsubsection{Group Alpaeonebria}

Three studied species:

-Nebria (Alpaeonebria) reichei Dejean 1826,

-Nebria (Alpaeonebria) bissenica Bielz 1887,

-Nebria (Alpaeonebria) reitteri Rybinsky, 1902,

A. Nebria (Alpaeonebria) reichei Dejean 1825

Species mentioned in Banat by Dejean (1837), also cited from Ukraine [26, 22, 23, 24] and Austria in Carinthia Südsteiermark [47]. Its availability in Ukraine, is rather doubtful (PANIN Ruslan 2017 personal communication).

Size 10-12 mm. Shiny black elytra. Head normally without red stain to vertex, except immature individuals. Extremities (mandibles, palps, antennae, tarsi) are flavescent. Femurs usually (72\% on average of the populations) are blackish brownish. The most of the populations studied (Făgăraş -Bâlea Lake 2085 m., Rodnei Mountains - lezer Lake 1825 m., Bucegi Mountains -Piatra Arsă 1950) have $28 \%$ of individuals with a red stain to the vertex and yellow femurs. This form could be confused with femoralis alpigrada Csiki. First antennomere is subcylindrical with a variable chaetotaxy of 1 to 3 bristles (1 long bristle and 1 to 2 short bristles implanted in the vicinity). The number of bristles varies according to the population, the most frequent being 2 bristles. For example, in Făgăraș (Balea Lac 2085 m.) 11\% of individuals hold 1 bristle, $88 \% 2$ bristle and $1 \% 3$ bristle. Second antennomere with a bristle above, third antennomere longer, with 3-4 bristles. The literature [20] mentions only 1 bristle.

The alae are very atrophied with triangular shape. (figure 4).
Individuals with appendages and legs totally yellow (often referred as ormayi alpigrada Csiki 1905 [32]).

Other common features: first antennomere ovoid, more or less elongated; ventrites 4-5-6 with one bristle on each side of the middle.

Three cases considered:

-first antennomere with two bristles of equal length, triangular ala. The form of Nebria (Alpaeonebria) reichei, no doubt related to transsylvanica in the past.

-first antennomere with one long bristle:

-triangular ala: Nebria (Alpaeonebria) reichei -ala in the form of S: Nebria (Nebria) femoralis alpigrada

Species widely quoted from the Southern Carpathians where it is found (Transfăgărășan road at various altitudes including the top $2200 \mathrm{~m}$, Retezat 1800 m, Bucegi 1900-200 m) but also present in the Eastern Carpathians (M. Rodnei 1800-2000 m.)

\section{B. Nebria (Alpaeonebria) bissenica Bielz 1887}

This species was considered as a variety of Nebria reichei Dejean 1826 for a long time and is still under this heading in several recent fauna classifications.

It is distinguished by (illustration in BARLOY et al., 2011):

-the difference in colour of the oral appendages, antennae and legs: flavescents at reichei, only lighten at bissenica

-the shape of the first antennomere: short and subovoid at reichei, conic at bissenica with 2 bristle of unequal length (as some populations 
of reichei, (figure 4), but distinct by the flavescence of the appendages and legs). -the number of the bristle of the submentum: 3 to 4 at reichei, 10 to 12 at bissenica.

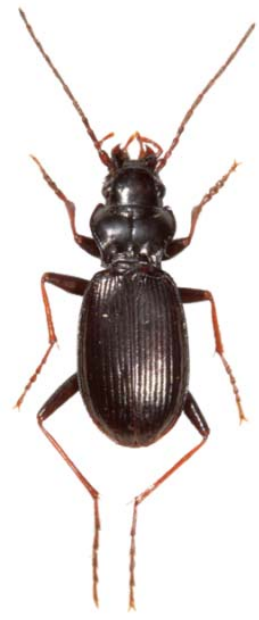

Black femurs
Nebria (Alpaeonebria) reichei Dejean 1826
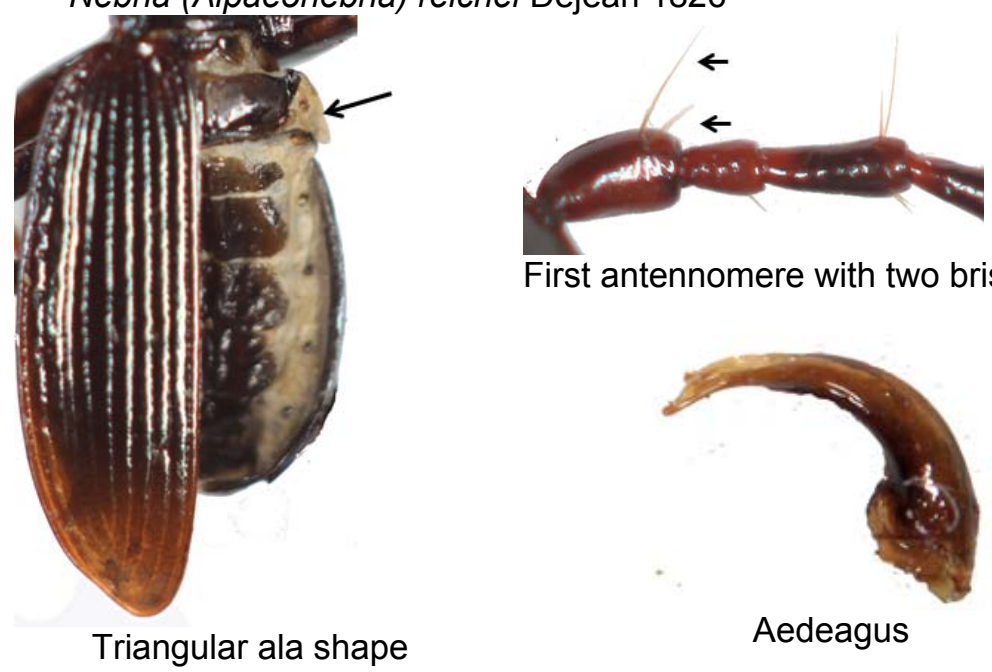

First antennomere with two bristles

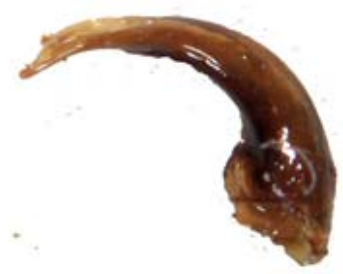

Aedeagus

Figure 4. Morphological aspects of reichei

Collected only in the Făgăraș Mountains, above the Transfăgărășan road tunnel, towards 2200 m., in the edge of streams of snowflake. Population mixed with reichei, sometimes transsylvanica and very localized.

\section{Nebria (Alpaeonebria) reitteri Rybinscky 1902}

Species also present in Ukraine: Chornagora (loco.typ), Gorgany, Marmarosh, (Panin R, personal com. 2017), Beskid [49], Transcappathia $[25,26,27,22,23,24]$ in subalpine zone 1300 $1650 \mathrm{~m}$.

Size 11-13 mm., black glossy concolored appendages or barely brigthened. First antennomere ovoid, with a long bristle (like femoralis), second article with a bristle below. Submentum with 4-5 bristles on each side of the middle. Black legs. Ventrites 4, 5, 6 with 2 bristles on each side of the middle (only one in femoralis). Shape of the ala in S, as in transsylvanica and femoralis.

Horvatovich cited rodnaensis as a subspecies of the Rodnei Mountains [50], also formerly considered as a subspecies reichei, currently invalidated [20].

Widespread in the Maramureș Mountains (Borșa 1000 m.), Mount Rodna (lezer Lake 1825 m., Mount Cisa 2000 m.), Cozia Mountains (Meteorological Station $1668 \mathrm{~m}$ ) on the banks of streams or in forest areas at high altitudes (1000 to $2000 \mathrm{~m}$.). Also cited by Merkl [38] of the Maramureș Mountains, Borșa Fântana Stanchii $1654 \mathrm{~m}$, and by Csiki [13] and Hurka [40] of the Rodna Mountains

\section{MOLECULAR DATA}

Some molecular biology studies have been dedicated in Europe to:

-species with wide distribution: jockischi, gyllenhali with an identification of the most appropriate markers

-Nebria brevicollis Fabricius 1792 with characterization of the entire mitochondrium [51]

-some other species (helwigi [52], salina [53], and GenBank).

To our knowledge, no studies have been carried out on the Nebria species form Carpathian Mountains.

\section{Nuclear marker}

This marker does not separate the species from each other but the subgenera with the exception of subgenus Nebria (transsylvanica, femoralis) and Alpaeonebria reichii that were confused with each other without significant variability. The distinction is clear between these two subgroups and Eunebria jockischi and Boronebria (gyllenhali) heegeri (Figure 5).

\section{Mitochondrial markers}

The analysis was done by concatenation of $\mathrm{COI} I$ and cyt b (1042 bp).

2.1. Global analysis (Figure 6) showed that all studied species are distinguished from one another with genetic differences (\% K2P) ranging from 7.8 (femoralis / alpigrada) to 14.2 (jockischi / gyllenhali). 


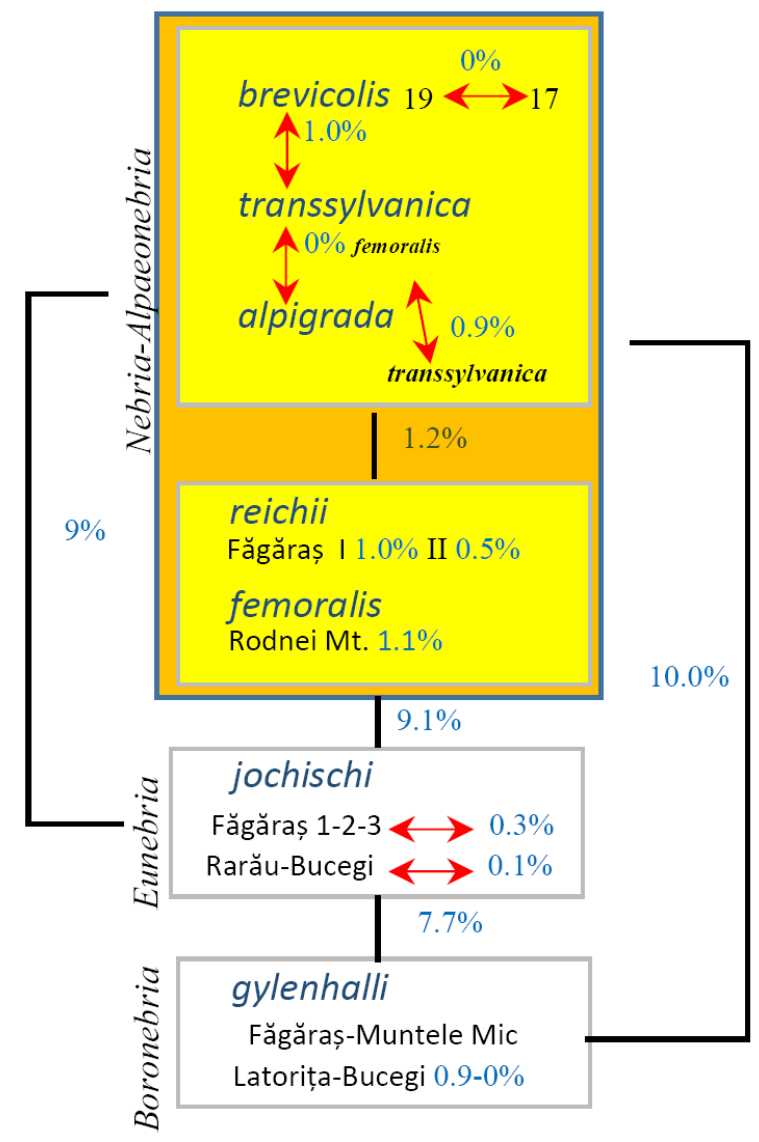

Figure 5. Marker 28S 5F5R

\subsection{Species analysis}

2.2.1. Nebria (Eunebria) jockischi hoepfneri Dejean 1826

The widespread species, exhibits variability (Figure 7):

-geographical: case of Rarău beside FagăraşBucegi-Muntele Mic

-altitudinal: the populations which are present at different altitudes (1550 to $2005 \mathrm{~m}$ ) along the Transfăgărășan road vary slightly at medium altitudes (1550-1613 m.) but different towards the summit (1844 m.) and especially $2005 \mathrm{~m}$. This suggests independent evolution.

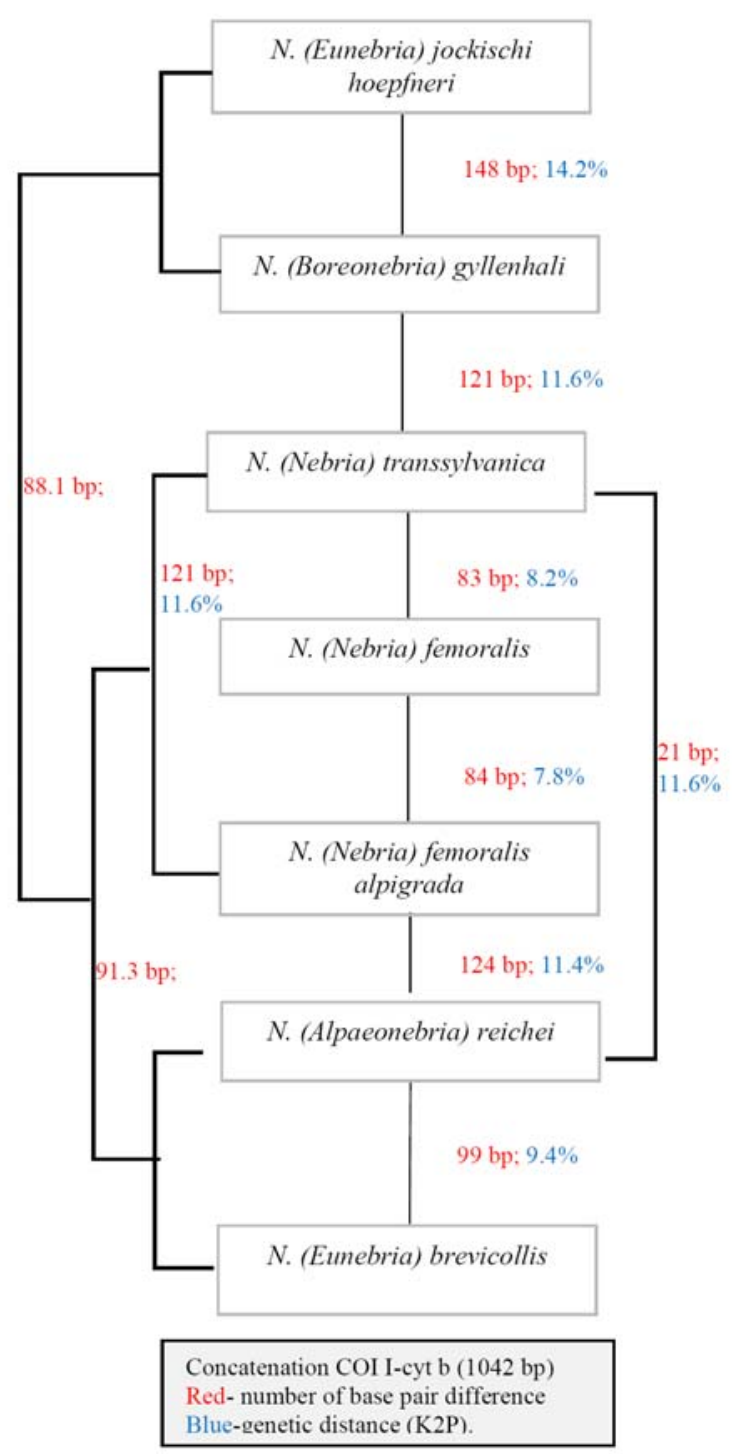

Figure 6. Interspecific distinction 


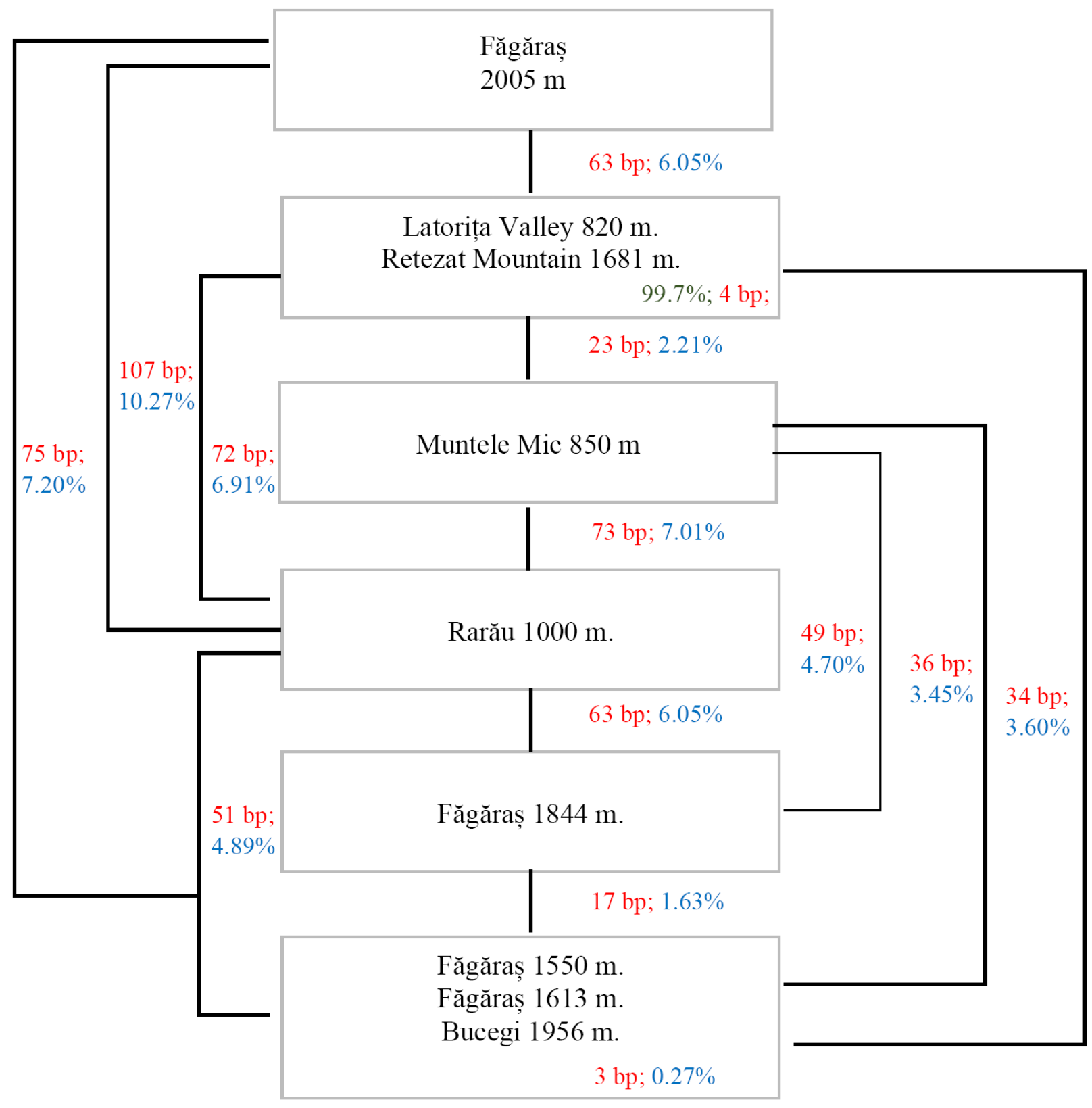

Figure 7. Nebria (Eunebria) jockischi hoepfneri

2.2.2 Nebria (Nebria) transsylvanica Germar 1824, Nebria (Alpaeonebria) reitteri Rybinsky, 1902, Nebria (Nebria) femoralis alpigrada Csiki 1905

The intraspecific variability is lower for femoralis ( $0.9 \%$ with 4 origins), strong (3.71\%) for alpigrada (3 origins). Nebria transsylvanica differs from femoralis alpigrada and reitteri by the same genetic distances (8.2\%) (Figure 8).
2.2.3. Nebria (Boreonebria) gyllenhali Schönherr, 1806 (=rufescens Strom 1768)

This very widespread species at the world level, partially studied from a genetic point of view, show a great infra-specific variability (K2P genomic distances between 3.6 and 15.2). These very important values require confirmation because they are not very compatible with an intraspecific status (Figure 9). 


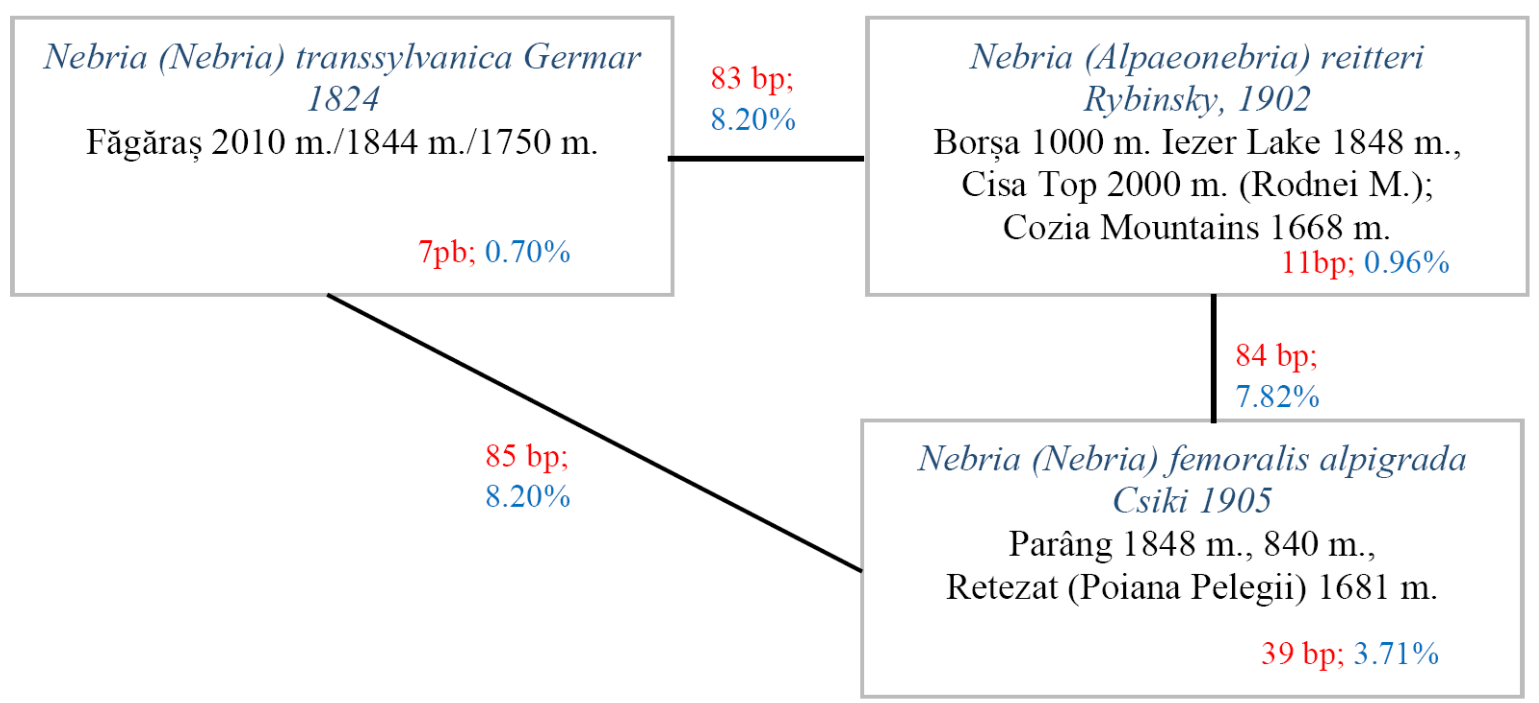

Figure 8. Nebria (Nebria) transsylvanica Germar 1824, Nebria (Alpaeonebria) reitteri Rybinsky, 1902, Nebria (Nebria) femoralis alpigrada Csiki 1905

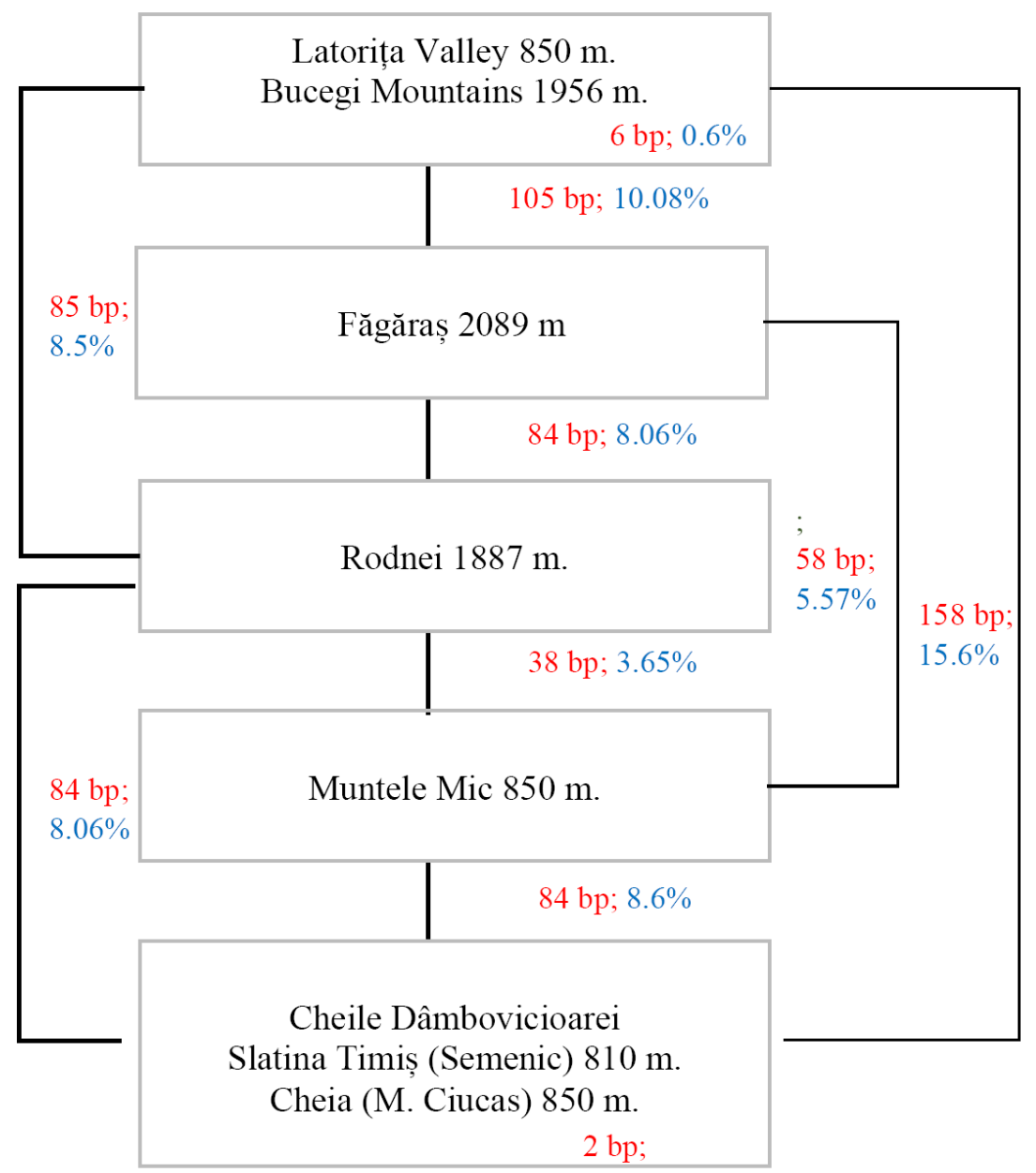

Figure 9. Nebria (Boreonebria) gyllenhali Schönherr 


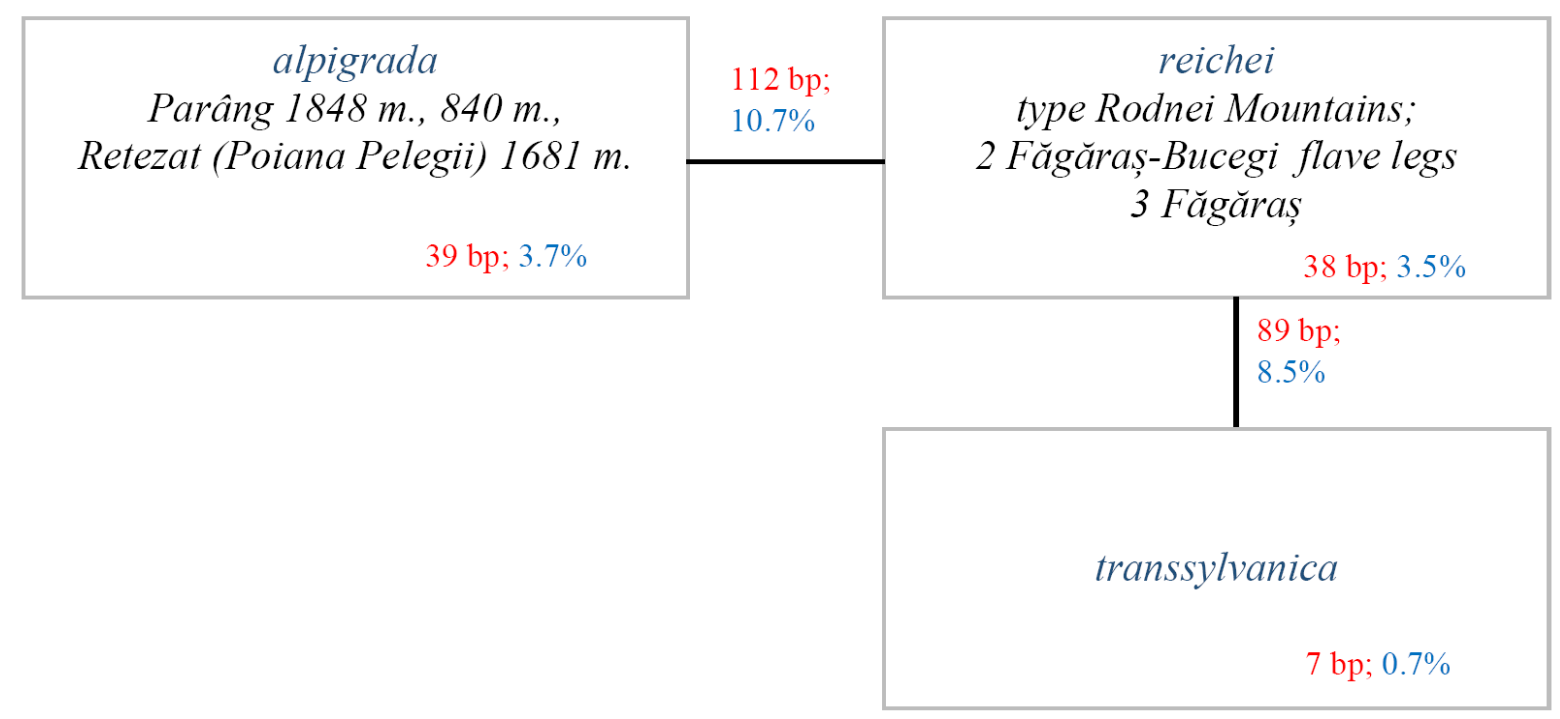

Figure 10. Group reichei/alpigrada

Nebria femoralis alpigrada differs from reitteri type by an average genetic distance of $7.8 \%$; the two origins being different: Parâng Mountains 7.5\%, Retezat Mountains 8.2\%.

Nebria femoralis alpigrada is heterogeneous with an intraspecific variability of $3.7 \%$, close to that found by RAUPACH et al (2010) for Nebria helwigi.

2.2.4. Group of Nebria (Alpaeonebria) reichei Dejean, 1826, Nebria (Nebria) femoralis alpigrada Csiki 1905

The reichei specimens with yellow coloured legs can be confused with alpigrada (however reichei has a triangular atrophied aileron, alpigrada has an S-shaped aileron).

Alpaeonebria reichei presents on average a significant intraspecific variability $(3.5 \%$ intrapopulation genetic distance) without distinction between the colour of the legs but with distinction of genetic nature:

-Bucegi/Făgăraș; Rodnei/Făgăraș: difference $5.3 \%$

-Rodnei/Bucegi/Bucegi: difference 5.5\%.

-reichei, which is genetically distinct from transsylvanica $(8.5 \%)$, is strongly differentiated from $N$. femoralis alpigrada (genetic distance $10.7 \%$ ) (figure 10).

\subsection{Nucleotide variations (study in COI I)}

The majority of substitutions observed between reitteri and femoralis alpigrada are being transition $(1.3 \%)$ :

-a neutral effect at reitteri (all amino acids identical)

-a modification of the nature of the amino acids for alpigrada, compared to reitteri. -provenance of Parâng Mountain: 2 amino acids of different biochemical class, methionine replacement by valine, valine by isoleucine -provenance of Retezat Mountain: alanine replacement by serine and asparagine by serine.

\section{Conclusions}

A. From a morphological point of view

1. Two common species: Nebria (Eunebria) jockischi hoepfneri Dejean, 1826 and Nebria (Boreonebria) gyllenhali Schönherr, 1806 occur in many mountain regions from the foothill to the summit with geographical and altitudinal variability (see molecular biology). Nebria (Eunebria) jockischi hoepfneri is distinguished by a red stain on the vertex, with a very similar habitus (notably wings are very developed but without established functionality). In the stain absence, it differs from Nebria (Boreonebria) gyllenhali by 2-3 bristles on each side of the ventrites 4-5-6 in contrast to a single one of gyllenhali.

2. Nebria (Nebria) transsylvanica, captured only in the Făgăraş Mountains has a habitus characteristic for the type and the alpigrada form.

3. Nebria (Alpaeonebria) reitteri must be studied from several provenances (the captures are only from Rodnei, Mountains, Borșa, Cozia).

4. Nebria (Alpaeonebria) reichei has very variable antenna chaetotaxy ( 1 to 3 bristles) such as the colour of the femurs (black or yellow) and appears to have marked geographical variability (see molecular biology). It is distinguished from other species by its atrophied alae of triangular shape. Some populations of reichei have characteristics similar to alpigrada but are identified by their 
triangular shape of the alae atrophy (alae $S$ shape to alpigrada and data of molecular biology).

5. Nebria (Alpaeonebria) bissenica, a species of high altitude and very localized, is distinguished from reichei by the lighter appendages and legs, two bristles of unequal length at the first antennomere of conical form (short, subovoid at reichei); the number of bristles on the submentum (10 to 12) being difficult to assess, given their fragility.

6. Nebria (Boreonebria) heegeri, a species of doubtful capture because it is difficult to separate from gyllenhali. Endowed with more reduced membranous wings and antennomeres with the same shape and dimension, heegeri has the second antennal segment provided with a bristle above and an other below, unfortunately fragile. It maybe more widespread than is indicated in the literature. The first antennomere is conical to Nebria (Boreonebria) heegeri and more oval, cylindrical to gyllenhali.

\section{B. In molecular biology}

1. Mitochondrial markers exploited in concatenation COI I / cyt b distinctly separate the studied species, with genetic distances (coefficient K2P) varying from 7.8 (reitteri / alpigrada) to 14.2 (jockischi / gyllenhali).

2. Nebria (Eunebria) jockischi hoepfneri has a great geographical and altitudinal variability (Făgăraș Mountains) like $N$. (Boreonebria) gyllenhali; the infraspecific variability is more moderate (3.5 to $3.7 \%$ ) for reichei and alpigrada.

3. Nebria (Nebria) transsylvanica is clearly identified by molecular data, which becomes a criterion for identification in case of rupture of the bristles of the first antennomere.

4. Nebria (Nebria) femoralis alpigrada morphologically distinct from reichei (yellow colour of appendages and legs) is also separated by molecular data.

\section{References}

1. Barloy, J., \& Prunar, F. (2011). Preliminary observations on the species of the genus Nebria from the romanian Carpathians. Research Journal of Agricultural Science, 43(2), 235-240.

2. Witkowski, Z., Król, W., \& Solarz, W., (2003). Carpathian list of endangered species. WWF and Institute of Nature Conservation, Polish Academy of Sciences, Vienna-Krakow. International DanubeCarpathian Programme. 44-46.

3. Bielz, E. (1887). Catalogus Coleopterorum Transsylvanie, Siebenbürgens Käferfauna. Verhandlungen und Mittheilungen des Siebenbürgischen Vereins für Naturwissenschaften, 37, 3-90.

4. Bielz, E. A. (1887). Die Erforschung der Käferfauna Siebenbürgens bis zum Schlusse des Jahres 1886. Verhandlungen und Mittheilungen des siebenbürgischen vereins für Naturwissenschaffen, 37 , 3-90.

5. Szél, G., Rozner, I., \& Kocs, I. (1995). Contribuţii la cunoaşterea coleopterelor din Transilvania (România) pe baza colectărilor din ultimii ani. Acta Muz. Secuiesc al Ciucului, Muz. Naţ. Secuiesc, 73-92.

6. Barloy, J., Prunar, F., Barloy-Hubler, F., \& Dreano, S. (2014). Preliminary study of C.(Morphocarabus) zawadzkii seriatissimus Reitter 1896 from Northern Romania. Research Journal of Agricultural Science, 46(1), 47-59.

7. Hebert, P. D., Cywinska, A., \& Ball, S. L. (2003). Biological identifications through DNA barcodes. Proceedings of the Royal Society of London $B$ : Biological Sciences, 270(1512), 313-321. DOI: 10.1098/rspb.2002.2218

8. Jermiin, L. S., \& Crozier, R. H. (1994). The cytochrome $b$ region in the mitochondrial DNA of the ant Tetraponera rufoniger: sequence divergence in Hymenoptera may be associated with nucleotide content. Journal of Molecular Evolution, 38(3), 282-294.

9. Katoh, K., Misawa, K., Kuma, K. I., \& Miyata, T. (2002). MAFFT: a novel method for rapid multiple sequence alignment based on fast Fourier transform. Nucleic acids research, 30(14), 3059-3066.

10. Guindon, S., Dufayard, J. F., Lefort, V., Anisimova, M., Hordijk, W., \& Gascuel, O. (2010). New algorithms and methods to estimate maximumlikelihood phylogenies: assessing the performance of PhyML 3.0. Systematic biology, 59(3), 307-321. https://doi.org/10.1093/sysbio/syq010

11. Fuss Karl (Carl) (1849) Die Siebenbürg. Arten der Gattung Nebria Latr. - Verh.Mitt.siebenb.Ver.Naturw. 1: 13-16. (1849/1850): 50-58.

12. Csiki, E. (1946). Die Käferfauna des KarpatenBeckens.

13. Csiki, E. (1951). Fauna jukov Gori Radna (Die Kaferfauna des Rodnaer Gebirge). Acta Biologica Academiae Scientiarum Hungarice, 2(1), 19-168.

14. Gîdei, P., \& Popescu, E. (2012). Ghidul coleopterelor din România, I, Ed. PIM, laşi.

15. Dejean, P. (1826) Species général des coléoptères de la collection de M. le Comte Dejean. Tome second. Mequignon-Marvis $501 \mathrm{pp}$.

16. Brandmayr P., Gobbi M., Scalercio S., Sapia Maria, Pizzolotto R. (2012), Mountain ecosystems in southern Italy and in the Alps: Faunal communities three decades after (1980-2010). XII Conf. Climate Change 27-30 August Croatia.

17. Mani, M. S. (2013). Ecology and biogeography of high altitude insects (Vol. 4). Springer Science \& Business Media.

18. Marcuzzi, G. (2012). European ecosystems (Vol. 15). Springer Science \& Business Media Press.

19. Raso, L., Sint, D., Mayer, R., Plangg, S., Recheis, T., Brunner, S., Traugott, M. (2014). Intraguild predation in pioneer predator communities of alpine glacier forelands. Molecular ecology, 23(15), 37443754. doi:10.1111/mec. 12649

20. Ledoux, G., \& Roux, P. (2005). Nebria: Coleoptera, Nebriidae. Faune mondiale Muséum [d'histoire naturelle de Lyon], Centre de conservation et d'étude des collections, Société Linnéenne de Lyon, pp 976. 
21. Schönherr CJ (1808) Synonymia Insectorum, oder: Versuch einer Synonymie aller bisher bekannten Insecten; nach Fabricii Systema Eleutheratorum \& c. geordnet. Vol 1 Eleutherata oder Käfer. Part 2 (CF Marquard, Stockholm) pp x 424, 1 pl., p. 196

22. Putchkov, A. V. (2008). "A Review of the Carabid Beetles of the Tribe Nebriini (Coleoptera, Carabidae) of the Fauna of Ukraine," in Abstracts of Papers of the International Scientific Conference Devoted to the Fiftieth Anniversary of the "Pozhizhevska" Biological Station (September, 23-27, 2008) (Lvov, 2008), pp. 345-346.

23. Putchkov, A. V. (2011). Ground beetles of the Ukraine (Coleoptera, Carabidae). ZooKeys, (100), 503515. Advance online publication. http://doi.org/10.3897/zookeys.100.1545

24. Putchkov, A. V. (2013). Survey of carabid beetles of the tribe Nebriini (Coleoptera, Carabidae) of the fauna of Ukraine. Entomological review, 93(5), 620-629. https://doi.org/10.1134/S0013873813050102

25. Rizun , VB. (2003) The ground-beetles of Ukranian Carpathians. Lviv, 208 pp. [in Ukrainian]

26. Rizun , VB. (1989). "Carabid Beetles (Coleoptera, Carabidae) of the Tribe Nebriini," in Biosystematics of the Structure of the Museum Collections of the State Natural History Museum of the Academy of Sciences of the Ukrainian Soviet Socialist Republic (Lvov, 1989), pp. 99-106, VINITI 13.03.1989, No. 1634-V89.

27. Rizun , VB. (2003). Turuni Ukrainskikh Karpat. Lviv, 210 pp. (in Ukranian).

28. Holdhaus, K., \& Deubel, F. (1910). Untersuchungen über die Zoogeographie der Karpathen (Vol. 6, No. 1). G. Fischer, pp 200

29. Petri, K. (1912). Siebenbürgens Käferfauna auf Grund ihrer Erforschung bis zum Jahre 1911 (Vol. 3). R. Friedländer \& Sohn.

30. Kutasi Cs., Tallósi B. (2011)- A Csukás futóbogarai (Coleoptera: Carabidae) Acta Siculica, 105111.

31. Ledoux, G., \& Roux, P. (1992). Le genre Nebria (Coleoptera, Nebriidae) II. Compléments sur le sous genre Alpaeus et analyse des sous genre Nebria. L'entomologiste 48, 5, 241, 254.

32. Csiki, E. (1905-08): Magyarország bogárfaunája 1. kötet Adephaga 1. Caraboidea.[The beetle fauna of Hungary 1. volume Adephaga 1. Caraboidea.], Budapest. Pp 81-240.,546

33. Kryžanovskij, O. L., Belousov I.A., Kabak I.I.,. Kataev B.M,. Makarov K.V, Shilenkov V.G. (1995). A checklist of the ground-beetles of Russia and adjacent lands (Insecta, Coleoptera, Carabidae) (No. 3). Pensoft publishers. Sofia. Moscow.

34. Germar, E. F. (1824). Coleopterorum species novae aut minus cognitae, descriptionibus illustratae. Impensis JC Hendelii et filii. XXIV+624 pp+2 pl.

35. Ganglbauer, C. L. (1892). Die Käfer von Mitteleuropa : Käfer der österreichisch-ungarischen Monarchie, Deutschlands, der Schweiz, sowie des französischen und italienischen Alpengebietes. Erster Band Familieriche Caraboidae Wien. Carl Gerold's Sohn. 557p, pp. 106.

36. Ganglbauer, C. L. (1896). Sammelreisen nach suedungarn und siebenbürgen. Coleopterologische Ergebnisse derselben. I. Theil. Annalen des
Naturhistorischen Museums in Wien, 11(häft 2), 164187.

37. Neculiseanu, Z. Z., \& Matalin, A. V. (2000). A Catalogue of the Ground-beetles of the Republic of Moldova: (Insecta, Coleoptera, Carabidae) (No. 17). Pensoft Publishers.

38. Merkl, O. (2008). Data to the knowledge on the beetle fauna of Maramureş, Romania (Coleoptera). Studia Universitatis Vasile Goldis Seria Stiintele Vietii (Life Sciences Series), 18. Supl. 244-311.

39. Merkl, O., Makranczy, G., Nemeth, T., Podlussány, A., \& Szél, G. (2011). Further data to the beetle fauna of Maramureş, Romania (Coleoptera). Studia Universitatis Vasile Goldis Arad, Seria Stiintele Vietii (Life Sciences Series), 1(21), 861-876.

40. Hůrka, K. (1975). Zur montanen fauna der Laufkäfer des Rodna-Gebirges in den Ostkarpaten (Coleoptera, Carabidae) Stud. Com. Muz. Bruckenthal, Sibiu, Şt. Nat, 19, 197-206.

41. Niţu, E. (2008). Species diversity of beetle fauna, a sensitive parameter for ecological monitoring. Maramureş Mountains Nature Park (Romania). Transylv. Rev. Syst. Ecol. Res, 5, 143-154.

42. Nitzu, E., Nae, A., \& Popa, I. (2008). The fauna of soil beetles (Edaphic Coleoptera) as a sensitive indicator of evolution and conservation of ecosystems. A study on the altitudinal gradient in the Rodnei Mountains Biosphere Reserve (the Carpathians). Advances in Arachnology and Developmental Biology, Vienna-Belgrade-Sofia Monogr, 12, 405-417.

43. Nitzu, E., Popa, I., Nae, A., Iuşan, C. (2008). Faunal researches on the invertebrates (Coleoptera, Orthoptera, Collembola and Araneae) in the Rodnei Mountains Biosphere Reserve. Travaux de IInstitut de Speologie «Emile Racovitza, 47, 3-52.

44. Montandon, A. L. (1908). Notes sur la faune entomologique de la Roumanie: Additions au catalogue des coléoptères. Buletinul Societății de Științe din București-România/Bulletin de la Société des Sciences de Bucarest-Roumanie, 17(1/2), 67-122.

45. Hoffmann, A. (1915). In der Transsylvanische Alpen. Wiener Coleopterologischen, 113-123

46. Gebhardt, A. (1932). Eine coleopterologische Studienreise ins Retyezât-Gebirge und zum SzurdukEngpasse. Wiener Entomologische Zeiting, 49, 137154.

47. Gebhardt, A. (1932). Ökologiai és faunisztikai vizsgálatok a zenoga medencében. Állatani Közlemények, 29, 42-59.

48. Banninger M. (1960). Nebria Bestimmungstabelle die Käfer Europas 2014. Mitteilungen Schweiz ent. Ges. 32 (4) 337-356

49. Rybinski, M. (1902). Coleopterum species novae minusve cognitae in Galicia inventae. Diss. Mathem. et pphys./Acad. Litt. Cracoviensis. Ser. B, 42, 1-8.

50. Horvatovich, S. (1972). Subspecific array of Nebria reichi Dejean (Coleoptera: Carabidae). Acta Zool. Acad. Sci. Hung. Budapest. 18., 297.

51. Linard, B., Arribas, P., Andújar, C., Crampton-Platt, A., \& Vogler, A. P. (2016). Lessons from genome skimming of arthropod-preserving ethanol. Molecular ecology resources, 16(6), 13651377. doi: 10.1111/1755-0998.12539. 
52. Raupach, M. J., Astrin, J. J., Hannig, K., Peters, M. K., Stoeckle, M. Y., \& Wägele, J. W. (2010). Molecular species identification of Central European ground beetles (Coleoptera: Carabidae) using nuclear rDNA expansion segments and DNA barcodes. Frontiers in zoology, https://doi.org/10.1186/1742-9994-7-26
53. Andújar, C., Hernando, C., \& Ribera, I. (2011). A new endogean, anophthalmous species of Parazuphium Jeannel from Northern Morocco (Coleoptera, Carabidae), with new molecular data for the tribe Zuphiini. ZooKeys, (103), 49. doi: 10.3897/zookeys.103.1124 